\title{
Scripta
}

\section{La llavor de Teresa. En el V centenari del naixement de Teresa de Jesús (I)}

\author{
Teresa's seed, in the 5th centenary of her birth
}

\author{
M. Mercè Gras Casanovas \\ mmercegras@gmail.com \\ Arxin dels Carmelites Descalgos de Catalunya i Balears
}

Aquest any 2015 s'ha celebrat arreu el V centenari del naixement de Teresa de Jesús, que ha fet vessar rius de tinta impresa en noves i velles biografies, reedicions, traduccions, facsímils i estudis crítics de la seva obra, tant escrita com fundacional, i on s'han prodigat els congressos, les exposicions, els concerts i les representacions teatrals...

Scripta ha volgut afegir-se a aquesta assenyalada efemèride de la santa castellana per excel lència, $\mathrm{i}$ ho ha volgut fer parant esment a alguns dels àmbits més perifèrics, que sovint no han rebut l'atenció dels estudiosos teresians, però on Teresa, la d'Àvila, va adquirir carta de naturalesa ben aviat per la gran acceptació que van tenir els seus escrits i per l'admiració que va despertar en la societat del seu temps la seva figura singular. El protagonisme d'aquesta primesa tramesa d'articles està centrat en els antics regnes de la Corona d'Aragó i en el territoris italians, com el regne de Nàpols, que hi van tenir tanta relació a l'època medieval, i encara després, en els segles moderns, i també a França, en un del primers Carmels fundats fora de les fronteres hispàniques per les deixebles de Teresa.

Hem volgut presentar la influència $i$ transcendència de Teresa de Jesús des de les diferents manifestacions culturals, en disciplines tan diferents com l'arquitectura conventual, la música de les celebracions de la seva santedat, en els escrits de les seves religioses, a casa nostra, però també arreu d'Europa, on es va establir el Carmel descalç, així com en l'empremta de la seva espiritualitat en la poesia catalana contemporània.

En el primer dels treballs, «La rete mediterranea della devozione. Le teresiane della provincia di Napolis, Vittoria Fiorelli analitza les particularitats de la fundació d'una comunitat de carmelites 
M. Mercè Gras Casanovas. La llavor de Teresa. En el V centenari del naixement de Teresa de Jesús (I).

descalces a Capri, en el Nàpols hispànic de mitjan segle XVII, per part d'una carismàtica religiosa, la mare Serafina di Dio, de qui és gran coneixedora. Els escrits de santa Teresa de Jesús van tenir certament una gran difusió a terres italianes des dels primers temps, impulsats per la congregació italiana de l'Orde, a la qual pertanyien tots els convents europeus del Carmel descalç fora de l'Espanya peninsular, i comptà també amb el recolzament institucional de les autoritats virregnals de la corona espanyola.

En segon lloc, amb «Pour la fête de notre séraphique mère sainte Thérèse: A Teresian Celebration in Verse, and a Concise View of French Carmelite Poetry», David H. Hanna presenta unes interessants reflexions, a partir dels rics arxiu de les carmelites descalces de Pontoise, sobre la influència a França de la tradició poètica teresiana de composició i la difusió d'aquests textos entre els diferents convents de carmelites descalces.

Per la seua part, a «Todo tosco y sin labrar: el model conventual de santa Teresa i el seu reflex en la normativa arquitectònica de l'orde carmelità descalç», el treball de la historiadora de l'art Carme Narváez, aquesta autora se centra en l'anàlisi del model arquitectònic que va establir la reforma teresiana a través dels diversos textos normatius emanats de l'orde del Carmel descalç en la congregació espanyola.

Després, Joan Requesens realitza una magistral i detallada aproximació a l'empremta mística de Teresa en un del nostres poetes més espirituals, Jacint Verdaguer, en el seu treball «Jacint Verdaguer, un poeta teresià fora vol». L'autor havia esgranat anteriorment i de forma seriada aquest anàlisi a les pàgines del blog castellinterior.wordpress.com, però en realitza ara una rica i reeixida síntesi que permet copsar com Verdaguer va interioritzar l'espiritualitat teresiana i en va pouar motius per a la seva pròpia obra.

En penúltim lloc, «The soundscape of the ceremonies held for the beatification of St Teresa of Ávila in the Crown of Aragon, 1614», és la contribució de les musicòlogues Tess Knighton i d'Acensión Mazuela-Anguita, on es realitza una interessant i suggerent aproximació al desconegut fins ara paisatge sonor de les cerimònies que celebraren la beatificació de Teresa de Jesús el 1614, a través de l'anàlisi de les relacions que es publicaren per part dels devots de la santa, mirant de situar aquests fenòmens musicals dins el seu context performatiu, social i cultural.

Clou el monogràfic la sempre interessant aportació de Verònica Zaragoza, gran coneixedora de la tasca poètica realitzada dins els murs de la clausura conventual femenina, que, al seu «Cual doctora en cielo graduada... La poesia femenina per als certàmens literaris amb motiu de la beatificació i canonització de Teresa de Jesús (València, 1614 i 1621; Barcelona, 1614)», traça un rellevant fresc de la participació de les religioses en els certàmens poètics celebrats en honor de Teresa de Jesús en les terres de parla catalana, Barcelona i València, en el context dels actes que celebraren la beatificació (1614) i canonització de la religiosa (1621).

Aquest primer lliurament de treballs centrats en la repercussió de la figura de la santa d'Àvila en 
M. Mercè Gras Casanovas. La llavor de Teresa. En el V centenari del naixement de Teresa de Jesús (I).

terres de la Corona d'Aragó és, només, una mostra del que es pot aportar, des dels espais fins a cert punt tangencials que hem indicat més amunt. Sense cap dubte, són fruit d'un treball assenyat i rigorós en arxius i biblioteques i mostren com, durant el llarg període que anomenem barroc -i encara després- la influència d'aquella dona excepcional va deixar-se sentir en la literatura, l'art, l'arquitectura i, evidentment, en l'espiritualitat. 